\title{
The Body and Transcendence in Emmanuel Levinas' Phenomenological Ethics
}

Fleurdeliz R. A/tez-Albela

\begin{abstract}
This paper is a presentation of Emmanuel Levinas' notion of corporeality that shows struggling dialectic from a phenomenology of a sensible subject towards an ethics of transcendence. With the author's attempt to show that the Good is given and received through sensibility held by the body dwelling in the world, she proposes that the seeming conflict between the seeming corporeal pull to dwelling as against the Desire to take an ethical flight can be settled when one courageously confronts the following truths about humanity: that human beings are, 1) more than their thoughts, as 2) they are made of flesh and blood and that 3) they are in and thus influenced by the world. Through the work of corporeality, the subject is weakened by pain despite virility, suffers despite being at home and longs for a sublime unknown in the face of plenitude. By the stern conviction that existence can also be obscure and indefinite for consciousness to old, Levinas is able to explain how an egoistic subject is humbled and prepared to welcome the Other.
\end{abstract}

Key words: Levinas, coroporeality, alterity, phenomenological ethics

A lterity is fundamentally construed as a mechanism that makes a subject consider the existence of another being. Such leads to the psychological-ethical alternative called altruism that may be considered as the provocative, compelling and sometimes, even haunting way to think about the welfare of this other.

While oftentimes considered altruistic, the notion of Emmanuel Levinas reveals not a simple and reflexive response to the desolate fellow. With the help of phenomenology and Biblical wisdom, this French-Jewish thinker is able to show that the radicality of human responsibility must be sourced from a deep-seated existential issue - and perhaps, a very disturbing one for being capable of reversing commonly reflexive human values to radical moral commitments. For Levinas, such starts with the notion of Escape-a primordial and persisting disposition to take radical flights from the binding ontology of totality, and perhaps, also the totality of ontology. This notion of escape is the fundamental glimpse to transcendence, or the constant impetus to the Infinite and the alterity of the Other-thereby marking the a departure to the ethical. 
As Levinas regards transcendence as an exodus to the beyond and a flight from one's limited Self, he specifically upholds that escape is also a quest for the true meaning of life, but not at distant heights. He echoes Rimbaud's "the true life is absent," though immediately counters it by facing the hard fact that, "we are in the world." Assuming that transcendence occurs through ethics, it must be the case that the exodus occurs here and now-among bodies. The following discussion will deal with the significance of the body and human embodiment in an ethics of transcendence. I will attempt to show that the Good is given and received through sensibility held by the body dwelling in the world.

\section{The Body in Levinas' Works ${ }^{2}$}

Levinas first echoes Husserl in affirming how human life is interwoven with the natural world. The fundamental principle of the lived body (Leib) shows the reality of man as part of the animalia-embodied entities whose consciousness are attached to (and so, is in a certain sense ruled by) vital existence. $^{3} \quad$ Yet as distinct from an animal, human beings possess consciousness that recognizes the natural unity of consciousness and the body as belonging to the world. ${ }^{4}$ Levinas creatively develops this notion by

1 "La vraie vie est absente. Nous ne sommes pas au monde."(The true life is absent. We are not to the world [translation mine]). Cf. Rimbaud's Une Saison en Enfer (1963) in Oeunres Complètes, 229, in Adriaan Peperzak, To the Other: An Introduction to the Philosophy of Emmanuel Levinas (West Lafayette: Purdue University Press, 1993), 132. Such line from Rimbaud expresses a complaint against infernal and extramundane (i.e., inhuman), existence probably referring to the nihilism of the contemporary age. It is a statement of frustration, where the speaker airs a desire to escape from suffering, boredom and violence. In Totality and Infinity, Levinas contradicts the second sentence by giving a reprimanding reminder that, "we are in the world." Emmanuel Levinas, Totality and Infinity: an Essay on Exteriority (Pittsburgh: Duquesne University Press), 21. This revisal constitutes a change in context, then expressing that transcendence does not entail a flight from worldliness and its object (despite its being up-there) has the experience of the humane world for its condition. Op. cit., 133. Also see Bernasconi, "No Exit: Levinas' Aporetic Account of Transcendence," in Research in Phenomenology, 35 (2005), 110.

${ }^{2}$ No specific work can be pointed out as the main textual key to Levinas' notion of the Body. Nevertheless, it appears as a recurring yet unexplained theme in most of his major works. One can gather together some strewn notes coming from Levinas' different works to see whether it is possible to develop a Levinasian dialectic on the Body and Corporeality. In doing so, the texts were provisionally divided into parts that reveal the fundamental progression of the mainstream Levinasian plantilla: a) The Influence of Edmund Husserl, b) The Early Works (On Escape, Existence and Existents and Time and the Other), c) Totality and Infinity and d) Otherwise than Being and Beyond Essence and other later works.

${ }^{3}$ Edmund Husserl, Ideas: General Introduction to Pure Phenomenology, trans. by W.R. Boyce Gibson (London: George Allen and Unwin Ltd., 1952), \39, 126.

${ }^{4}$ Husserl admits the clear distinction between the essences of consciousness and that of the material world as he adheres to the Cartesian dualism of pure ego and extension. However, the work of ego-consciousness, even if occurring outside any worldly object still begins with sensory experience as its ultimate source. Part of the rigour of consciousness is a reflection capable of finding valid means to determine itself. As it manifests both the psychological and phenomenological glances of man, consciousness needs the body for the 
emphasizing sensibility as an affective attitude towards the "horizons"- the marginal cogitatum, which expresses the exteriority of any object of the mind, ${ }^{5}$ animating consciousness. ${ }^{6}$ Levinas' reading of Husserl then provides: 1.) the dialectic liberation of the Body from being a mere empiric datum and 2.) provision of a gnoseological foundation for affectivity, which is not constitutive of representation. Noticeably, Levinas begins a schema of human subjectivity that is geared towards an ethical acceptance of the exterior, the Other.

In the early texts, Levinas finds the Body as a dialectic medium in describing the existential condition of escape and the condition of a subject that is struggling against the enrootedness of presence and position. In $O n$ Escape, he mentions irate bodily conditions (malaise? ${ }^{7}$ nausea $^{8}$, and vertigo ${ }^{9}$ ) that trigger escape. ${ }^{10}$ In Existence and Existents and Time and the Other, he describes

empirical validity of both psychological and psychophysical realities. For Husserl, an ego operating apart from any bodily organ is essenceless and is an "empty looking of an empty Ego." Husserl particularly notes in Ideas: He provides an initial explanation to this in Ideas: "(in genuine perception)... we can 'confirm' its presence in the actual context of experience, eventually with the help of correct empirical thinking, then the perceived thing is real and itself really given, and that bodily in perception." Ibid., $\$$ 39, 127 .

5 Emmanuel Levinas, The Theory of Intuition in Husserl's Phenomenology (Evanston: Northwestern University Press, 1995), 20-21.

${ }^{6}$ For Levinas, such horizons accompany any object of the mind but remain at the background of conscious life not because of its obscurity but because they slip from what can be understood here and now. For Levinas, such are neither precedent to the work of the ego, and nor do they arrive as certain projections. Horizon is the halo surrounding the act of cogitation that cannot be deduced from the past and could just be a form of tentative or potential consciousness. See Ibid. It exists in all acts of consciousness (acts of memory, imagination, pleasure, will, etc.) and in varied forms (acts of belief, pleasure or displeasure, desire, tentative judgments, resolutions, etc.), paying tribute to the forgotten landscapes of obscure reality that is nonetheless lived. Emmanuel Levinas, "The Ruin of Representation," in Discovering Existence with Husserl (Evanston: Northwestern University Press, 1990), 116. Now, among these horizons include the human affect that rises in different and unexpected intensities. Levinas, The Theory of Intuition in Husserl's Phenomenology, 21. With the help of the Body as the perceiving subject, marginal consciousness in sensation is intensified to a sensibility, rising the usual perceptive contact to an affect, a deep-seated passion revealed in thought. Levinas, Discovering Existence with Husserl, 117. Also see Levinas, "The Permanent and Human in Husserl," in Ibid., 132. Reciprocally, corporeal existence also finds a fuller sense through horizons insofar as they are constitutes of consciousness. True enough, deep-affectivity is reflexively experienced through an awareness of and in the Body.

7 For Levinas, malaise reveals the longing to be loosened from a very unbearable situation despite the absence of the knowledge of what should be bearable. See Emmanuel Levinas, On Escape (De l'évasion), trans. Bettina Bergo (Stanford: Stanford University Press, 2003), 58-59.

${ }^{8}$ Nausea precludes un mal an coeur (an inner heave - as when one has a heartburn, upset stomach, or "sickness of the heart," a revolting presence of ourselves to ourselves that seems to be insurmountable then leading to a full-blown fever, headache or vertigo. For Levinas, nausea best expresses the misfortune of being enclosed. See Ibid., 66-67, 104.

9 Vertigo - a drowning dizziness accompanied by a terrible headache. In such sickness, human being realizes oneself in a void, a bottomless abyss which is actually the absence of a place hence, the there is. Ibid., 68.

${ }^{10}$ Vertigo, malaise and nausea are all expressions of the instinctive refusal of being shut into the anonymity of just buoying with the abysmal there is and the monotony of being 
the Body as preoccupied with things and needs brought by the existent's entrapment to position and place. The Body is then found as an "advent of consciousness", the very first possession of the subject and the locus of substantiation. For Levinas, conscious life owes itself not to the spirituality of the soul, but to a position where the subject realizes the condition necessary for any inwardness. ${ }^{11}$ By that, the Body provides the phenomenological experience of "here"12 - it is an event, and not just a bearer of life. In Existence and Existents, Levinas attunes this corporeal outlook to his project of transcendence by explaining EMOTIONS as that which destabilizes the existent. This is specifically present in moments of discomfort (enclosure and entrapment; irritation to anonymity; powerlessness and helplessness), conformity to location (sleep ${ }^{13}$, indolence ${ }^{14}$ and fatigue ${ }^{15}$ ) and resistance to enrootedness (by the effort to respond to higher needs, such as $\operatorname{eros}^{16}$ and paternity ${ }^{17}$ ). In Levinas' early works we already find an admission that the

stuck into the subcutaneous substantiality of one's subjectivity. John Llewelyn calls them as expressions of ontological claustrophobia - the fear of abiding by what has been determined within the boundaries of fundamental ontology. See Emmanuel Levinas: The Genealogy of Ethics (London: Routledge, 1995), 9-20.

${ }^{11}$ Levinas thinks that its spirituality, proven by its power to express, is not derived from a principle of animation but from the Body's position where the subject realizes the condition necessary for any inwardness. Emmanuel Levinas, Existence and Existents (The Hague: Nijhoff, 1978), 70. Indeed, it is only the Body that can provide an authentic phenomenological experience of here - the contact with matter and an external order of events and the internal experience-coenesthesis --internal experience made up of possession—of the subject as Self. Through the Body, the human being owns oneself while being possessed by life in all its elusiveness. Ibid., 69.

12 Ibid.

${ }^{13}$ Sleep is a comfortable withdrawal into the plenum. To sleep is to lie down and limit existence to an intimate place that one may call a home (le chez-soi) for a free self-abandonment in order to gather energy for a new start. Ibid., 67.

14 Indolence is the joyless aversion to the weight of being, it is to lag behind the duty to live. Levinas describes indolence or laziness by adapting William James' famous example - as when one is in between the obligation of getting up and the putting of the foot down the bed. It does not come from the lack of deliberation, it occurs after the intention when there is already repugnance to effort. It is a recoiling attitude towards beginning - a hesitation to proceed, an inhibition to begin, like when one is threatened by an obstruction or when jolted by an instant that presupposes another beginning. Ibid., 12-13. It is to mull over the uselessness of possessing or taking charge of something. But beneath this hesitation is the "bad conscience" i.e., the bothersome thought of the possibility to overcome it, to finally do something. Ibid., 15.

15 Fatigue, on the other hand, implies the precedence of human effort, coming after the experience of the weight of existence. It comes out of effort after I realize that I am condemned and forsaken to take on a heavy yoke. Upsurged by one's commitment (i.e., care ala Heidegger), there is also a sense of despair of a finite being who is too little for his ambitions and too weak for the world, hence a tendency to let go, to "drop everything." Ibid., 20. While effort can be victorious by overcoming its immanent challenges - fatigue is a recoil, it is the failure to reach its ascertained trajectory. "Effort lurches out of fatigue and falls back into fatigue." Ibid., 19). When I surrender out of fatigue - forces are exhausted for nothing, the effort exerted only goes back to the originary void. Fatigue is the endpoint of the upsurge of human force, coming as a form of despair because of the realization of human finitude.

${ }^{16}$ Emmanuel Levinas, Time and the Other and Additional Essays, trans. by Richard A. Cohen, (Pittsburgh: Duquesne University Press, 1987), 88-89.

${ }^{17}$ Ibid., 90-92. 
Body, despite bearing events leading to transcendence will always be the Self's riveting base. The subject will have to bring himself-his very concreteness, along in his travels. With Levinas' acceptance of the Body having the limits of human existence and the world to which it belongs, we find a dialectics of corporeality already based on human subjectivity, with the Body as a constituent of an entity that strives to hypostasize, to emerge as a Self.

In Totality and Infinity, Levinas turns to treat the Body as capable of several riveting feats of transcendence. He elaborates human sensibility as affected by life, the world and its consequential economy; hastened by the role of the Body as an ambiguous extension of the will that strives to work on objects for security and self-possession. ${ }^{18}$ For Levinas, human corporeity is an "ontological regime" that may resist the egoism of the will. The Body, in its own mode can express truths that put into question the compelling character of the will in a voluntary act. (What can a good person do while in comatose? What exam can a brilliant student pass when he cannot even come to class since he is sick? What can a virtuous activist fight for after a hunger strike?) Will could not be on its own, it must operate alongside a Body that has its own mechanical struggle for life. ${ }^{19}$ Such now calls for a good interplay between the will and the Body, then enjoining the subject to be concerned about this relation.

The Body in its concrete presence and relation to will through a voluntary act, also reveals the Self's entry into the calculative tendencies of the Other. ${ }^{20}$ Through which, the interaction of wills is possible, then yielding to trade of goods (commerce) or plain coexistence in time and space (sharing of history). Necessarily tending to a relation, this subject will always have to communicate (ex-press) — that implicitly evokes a response (ex-tend). This contention is furthered by Levinas' concept of sensibility as affected by life, the worldy and its consequential economy. ${ }^{21}$ To be more particular, Levinas is already considering the Body as capable of responding, most especially to the

${ }^{18}$ Levinas, Totality and Infinity, 226.

${ }^{19}$ Levinas writes: "In the exaltation of biological life the person arises as a product of species or of impersonal life, which has the recourse to the individual so as to ensure its impersonal triumph." Ibid., 120.

20 The body, where expression can dawn forth and where the egoism of the will becomes discourse and prima opposition, at the same time conveys the entry of the I into the calculations of the Other. Ibid.

${ }^{21}$ Sensibility is not an inferior theoretical knowledge bound intimately to affective states: in its very gnosis sensibility is enjoyment; it is satisfied with the given, it is contented. Sensible "knowledge" does not have to surmount infinite regression, that vertigo of the understanding; it does not even experience it. Ibid., 136. Sensibility, in its affectivity, is the very mode of enjoyment. Due to that, there is already an implied prescription that it should even be a flight from "consciousness of..." It is not separated from thought nor from its object although it does not aim at an object. The intensity of enjoyment in sensibility dissolves consciousness' concern for the object. Levinas writes: "sensibility, essentially naïve, suffices to itself in a world insufficient for thought." Ibid., 135. Sensibility is an encounter of a thing without troubling oneself of grasping its essence, nature, function and other abstract qualities. It is a concrete, hence embodied encounter of a concrete thing as when one takes delight on gourmet food, swims at the beach, walks under the sun, etc. Ibid. Also see ibid., 175, 226-228. 
following proddings of the exterior: need (through nourishment, ${ }^{22}$ enjoyment ${ }^{23}$ and work), ${ }^{24}$ the Face ${ }^{25}$ (through ethical responsibility) and the Society (through justice $)^{26}$.

22 Nourishments are alimentations - food, stuff that are taken in. They respond to hunger, a metaphysical concrete that expresses a material yet vital lack. Levinas, Time and the Other, 116. It is through which the Body responds the subject's most fundamental need. Nourishments provide the fuel (carburant) necessary for the "functioning" of existence that without them life ends. They are lived contents that feed life and does not have a direct relation with the human will. For Levinas, satisfaction through nourishment always follows with an "enjoyment from," a pleasure that does not require an appropriating and pre-occupied mind. "Enjoyment is precisely this way the act nourishes itself with its own activity." Ibid., 111. To respond to vital bodily needs is a form of enjoyment, an affirmation of life

23 Levinas writes: "Life is a love of life, a relation with contents that are not my being but more dear than my being: thinking, eating, sleeping, reading, working, warming oneself under the sun. Distinct from my substance but constituting it, these contents make up the worth (prix) or my life. When reduced to pure and naked existence... life dissolves into a shadow. Life is an existence that does not precede its essence. Its essence makes up its worth (prix); and here value (valeur) constitutes being. The reality of life is already on the level of happiness, and in this sense beyond ontology. Happiness is not an accident of being, since being is risked for happiness. Ibid., 112.

24 Through labor, the hand is empowered to explore on the possibilities of an object (hence, has a particular hold on the indefinite which is an attempt to transcend). However, such is a determined tweaking - an act of comprehension. The hand contours the raw material according to the goal of need. Through labor, the object is subjugated by the hand that tears, crushes or kneads hence putting a new order in it, turning it into a furniture/furnishing - a meuble that is transportable into a home. Nonetheless, despite the mastery of the subject through his hand, Levinas still accepts that labor is somehow conditioned by dwelling. This fact is most evident in the subject's Body which is the utmost possession that is maintained in a home at the very limits of interiority and exteriority. See ibid., 160-161.

${ }^{25}$ For Levinas, the whole Body of the Self testifies to what is expressed by the Face, because reality of the Other breaks forth from her very Face. As mentioned in the previous chapter, it would seem that the Face is a steady proto-type; but it is neither a representation nor a thing at hand - it is an irreducible means of access (notice such paradox). More than what it has already Said, Face signifies through its Saying - through a hovering revelation that refuses to persist. The Face reveals itself even if it refuses to give itself. Through sensibility one finds out that the Face goes beyond being mere presence and appearance because its unfolding falls short of the capacity of the subject to grasp. Levinas, Totality and Infinity, 169, 176. "The Face is present in its refusal to be contained. It is neither seen nor touched - for in visual or tactile sensation the identity of the I envelops the alterity of the object, which becomes precisely a content." Ibid., 194. And it is at this stance where we can call this post-phenomenon Face as an epi-phenomenon - stressing epi - as prefix for "over or out." Levinas, Time and the Other, 61. From which, we get the idea of an epiphany, which is an active principle of ex-pression and extension.

26 The ethics of this larger Body entails a more foreboding response. In order to accommodate the autre, Levinasintroduces the mechanism of justice that allows the Self to be responsible to all and for all. "Justice is the way in which I respond to the face that I am not alone in the world with the (single) other." Emmanuel Levinas, "The Provocations of Morality," in The Provocations of Pbilosophy: Rethinking the Other, ed. by Robert Bernasconi (London: Routledge, 1991), 174. This bigger responsibility is indeed a heavier burden because it demands for the use of reason that hypes up the ethical relation through discourse yet threatens the scope of responsibility that the subject may address. This rationality then calls for an overcoming of rhetoric which could be ruse, emprise and is a clear form of exploitation. See Levinas, Totality and Infinity, 72, 202. For Levinas, this difficult order specifically occurs in the realm of totality, and through arbitration of the State that should also be cautiously dis-inter-ested. Levinas, 
Levinas' most radical regard of the Body is in Otherwise than Being or Beyond Essence, where we find sensibility through amplified affects (pain, wounding, fatigue, patience, persecution) that depict the subject's struggle to Be-for-the-Other. ${ }^{27}$ Subjective sensibility is already identified as giving and breaking; disposed and exposed to wound, outrage and persecution. ${ }^{28}$ From these radical sensibilities, three ethical moments are then illumined: 1) Saying - the risky uncovering of the Self which breaks human inwardness by allowing oneself to be exposed to traumas and pain, hence be vulnerable to suffering $^{29}$, 2) Sacrifice-the struggle to exist despite oneself-a patient

Levinas, "Diachrony and Representation," in Entre Nous: Thinking-of-the-Other, trans. by Michael Smith and Barbara Harshav (New York: Columbia University Press, 1998), 165.

27 In this work, Levinas' take on sensibility still echoes that of Husserl's contentions. But this time, he is already pertaining to an awareness that gives up the very strength of consciousness. With the connection of sensibility to affectivity, what Levinas specifically means here is to be affected. Here then is a more concrete and provocative context of subjectivity as a sensibility since it already demands for the rupture of the contained cogito in order to welcome the uniqueness of the forgotten horizons that overflow. This radical sensibility is possible only through an exposure of the Self where one becomes vulnerable. Levinas, Otherwise than Being or Beyond Essence, trans. by Alphonso Lingis (Dordrecht, Netherlands: Kluwer Academic Press, 1991), 54. Such very revealing exposure already exceeds presence - this is already one's givenness. For Levinas, the subject's exposure to the Other is the most passive and unassumable passivity. It is the subjection of the subject who is obsessed with responsibility to the Other who is calling one's aid. Ibid., 55.

${ }^{28}$ Levinas notes that to be exposed means the subject's susceptibly to pain and facing the threat of exploitation. But this susceptibility could not be a vain display of weakness. "The exposure to another is disinterestedness, proximity, obsession by the neighbour, an obsession despite oneself, that is a pain." Ibid. For Levinas, pain is experience of exploitation. It is a physical adversity that puts human strength into question yet calls for an endurance for the sake of the Other. It is a bodily experience of struggle, fatigue and the passing of time (ageing) that the Self goes through when already inflicted by the call of the Other. With this experience is also a call for patience, the urge to hold go against the temptation of human fatigue. In the intensity of pain, one finds the passivity of sensibility as a vulnerability; as it hurts most where the Self is truly affected, his conscience (moral consciousness) - pierced by the provocation of the Face. Such is not necessarily evident through physical discomfort, but it will have to appear as a kind of inner heave. This pain is an interruption of my enjoyment. This pain tears me from myself, and renews my self-determined generosity to an authentic act of goodness. Ibid., 55-56. As a passivity in the paining of the pain felt, sensibility is a vulnerability, for pain comes to interrupt an enjoyment in its very isolation, and thus tears me from myself. This moment of sensibility as vulnerability and pain is both a moment of being exposed and disposed; of presence and hostage; of existing, breaking and finally - giving.

${ }^{29}$ Levinas graphically describes this exposure as a denuding of the Self, the "risky uncovering," the breaking up of inwardness. This is not a simple removal clothes because such stripping off goes as far as exposing a skin laid bare, a denuding of denuding. "A denuding beyond the skin, to the wounds one dies from, denuding to death." Such radical revelation also shows the subject's very uprightnedness since this also entails the exposure to outrage and wounding. And the limit of this stripping bare is the skin's incision, which signifies the separation of the subject from one's adherence to esse. For Levinas, such tearing is a painful flight from the Self. Ibid., 49. By engaging in an ethical discourse, through Saying, the subject runs the risk of being stripped off one's essence (of one's being in and for itself) and shelter. Part of being denuded in an exposure is to be exiled where the Self is de-centered, de-posed and delivered without any refuge. This exile, which is a flight without any direction, is a detachment and absolution from identical quiddity. Levinas notes that such absolution is nonetheless heading to a reversal of essence then orienting this renewed subject towards a dis-interestedness. 
resistance to remain in the Said by Unsaying, in order to Say the Unsaid-to lose (Unsay) the Self (Said) in order to welcome (Say) the Unsaid (Other), ${ }^{30}$ and 3) Substitution-that speaks of Infinite, the extent of responsibility; for Levinas, to substitute is the radical expression of being for the Other-an unassailable obsession to be for the Other and every other. ${ }^{31}$

\section{The Body, Embodiment and Transcendence}

It would seem that the obvious is just being stated, but a more vivid depiction of the ethical encounter (i.e., Encounter of the Face) depicts the relation between the body, the world and consciousness that goes beyond their respective "mechanisms". The interplay of these three will reveal a relation that nullifies its very relation-enigmatically, it is a relation without a relation

Levinas renders a quite crude context of the Body as he allows through it the possibility of breaking towards the ethical proven by his intense descriptions of pain, suffering, persecution and even death. Perhaps, Levinas opts to proceed with such a disintegrating transition to present the existence of tension which hints a distinction between consciousness (as oriented to the sovereignty of Infinity) from materiality, through the Body which will have to operate in its own accord. The relative independence of the Body is found governed by physical laws that no powerful yet abstract consciousness (Ego) can break. No will desires a disease: one may get sick due to his/her own doing, yet it could not be true that a person strives aspires to be sick. The mechanism of the Body is as elusive as life. In its own order, the Body has ways to sustain life and defend it from extinction. This Body is finite. Vital existence depends on breathing, pulse and movement which are all concretely

30 "Life is life despite life." Ibid., 51. It is the moment of keeping up with existence despite the odds, and even despite oneself. Levinas expresses human sacrifice in despite oneself which he thinks is essentially corporeal. It is an element of sensibility that accepts the possibility of pain and endures it upon occurrence. Such calls for strength in order to withstand, not necessarily the tension when one goes against pain, but the hurting of that very pain. To exist despite oneself means to accept the adversities the goes along with pain - the twitching itch of the wound, the hardships of labor, the malignity and mystery of a disease. While living despite oneself is not calling for an apprehensive attitude to life's maladies, neither does it is imply a vain surrender. Sacrifice as despite oneself for Levinas is a call for a moral drive to courageously face the hard conditions of life within the passing of diachronic time.

31 This pain is hastened by persecution where the subject openly receives the utmost form of exploitation due to an obsession brought by being held hostage by the Other. Indeed, a persecuted subject could but live in the hands of the Other - and with such horrifying pain and oppression, there seems to be no choice but to succumb to such anarchy. For Levinas, obsession is the radical form of passivity since it is where the subject falls, or makes a pure surrender. It is also with the same obsession where the terror of pain and persecution can be sustained through the inspiration of the Other. Radically, the obsession converts the persecution into an act of mortification for the violence imputed by the persecutor. Indeed, such manifests the nobility of the accusative and leads to the most radical form of responsibility where the subject is sub-jected to everything, substitution. And for Levinas, going through all the pain is the road to this utmost expression of subjectivity. See ibid., 114-115, 117. 
provided to the Body. Indeed, it is only the Body by its own mechanism, that speaks of its own extinction-not consciousness, and not even time. ${ }^{32}$

It might be better to think that the relation between the Body and the World is integral since both are organic and vital; but the relation between the Body and Consciousness despite Levinas' integral designation is ethical. Body and the world depict a tautologous finitude. Through position, the concrete and finite Body is conquered by situation (as provided by the world and existence). And in seeking its place in the world, the Body becomes flexible. With this, the body is found: 1) to carry the weight of existence (the Body is a natural receptacle), 2) to adapt with the circumstance provided by dwelling, (Body struggles for both survival and transcendence) or 3) to have wounds or die, (the Body is finite).

The Body then is an effective agent to speak of Levinas' ethics of transcendence. This is possible by understanding the Body as a vital metaphor33 - a living image, a Said escaping through its very Saying. This works for proving both the authenticity of this radical human provocation and the effectivity of Levinas' philosophical dialectic. Indeed, the Body, by its ostensiveness, is an obviously important component in justifying the whole of human existence. The Body serves as an apodictic base for justifying empiric epistemological processes, and an ontological ground to make further sense of substantiality and singularity. But likewise, this Body can be used in a dialectic

32 The precedent claim of Levinas' account of the banality of mortality is hereby being echoed. The mind's bearing of death includes the awareness of its inexorable occurrence that in Totality and Infinity, Levinas admits consciousness' natural resistance against it. The givenness of death is the very justification for the natural tendency to defend existence in time. "To be temporal is both to before death and to still have time, to be against death." Levinas, Totality and Infinity, 235. Human mortality, due to the finitude of the Body implies a necessary order that every human being will have to confront.

Meanwhile, In Otherwise than Being or Beyond Essence, such cognizance of the Body's independence is expressed by Levinas' open acceptance of its susceptibility to pain and suffering through magnified (i.e., overblown) exposure and nudity. Graphically, the vulnerability it implies can only be realized through an outburst (perhaps by wounding) and the shameful exposure of the human skin. Nonetheless, it could also be in the same rupture where the subject refuses to remain enrooted that one succumbs to the threats of vital discomfort to conquer a higher form of discomfort. This becomes transcendence of a radical form since the subject will have to survive the pains of breaking through. Herein, the call to go beyond entails a courageous scraping, a painful flight through a cut - at the expense of one's care for the skin.

33 This designation is created by the proponent as sourced from the concreteness of the Body and to the many other significations that it can reveal. This is specifically patterned after Levinas' priority of the Saying over the Said, inasmuch as Saying is more capable of being liberated from thematizing phenomenon of signs. He says, "the said and the non-said do not absorb all the saying..." Levinas, Otherwise than Being or Beyond Essence, 23. In Saying occurs the Unsaying of the Said, as well as the Saying of the Unsaid. Ibid., 44,46. Vital metaphors are concrete images that overflow vision as they indicate movement, time and position - hence life. They cannot be trapped signifiers, they are ever anew. By the very nature of embodiment as organic and vital yet transcendent, the proponent then poses the body as a vital revelation of its own excendence (from being a mere machine). Through the designation of the Body as a vital metaphor, we may graphically describe this fundamental human extension as a material substance that gives itself to consciousness, then gradually explodes in its strife to signify, by Saying more. Also see ibid., 25-26, 49. 
that explains transcendence through the very immanence of the human subject. The Body, as a vital metaphor, provides ways of speaking of transcendence by referring to 1) its relations with objects that it encounters and the situations where it is immersed (with the world and consciousness); and 2) the manifold ways which can provide a picture of the whole situation of ontology.

Corporeality, on the other hand, pertains to being embodied, a condition that reveals a relation between the Body and consciousness. In this stage, an integral lived body ${ }^{34}$ that clearly affirms the subject's having and being a Body is found. This then implies the subject's awareness of the nature and the functions of one's embodied existence. Just as how the physical body belongs to materiality (i.e., the world), the connection between the Body and consciousness is integral. This could be the start of the ethical dialectic. In elaborating the gnoseological relevance of Husserl's forgotten horizons, Levinas ends up honing a radical phenomenology of sensibility which culminates in the subject's encounter of the Face. While it is oftentimes said that ethics starts with the encounter of the Other in the Face; it could have started at corporeality, at the moment of self-embodiment.

There is ethics at the non-appropriating integration of the Body and consciousness. The conscious state that claims an identity and possession oriented to the world, connotes a relation between the Body and consciousness that are both cautious about the way they handle each other. Consciousness albeit its transcendental phenomenality as Pure Ego and claim to the body, will have to respect exclusively physical instances; and the Body as subject to the demands of the will acts not only out of obedience, but also out of respect for human prowess, of which affirmation is the first step to substantiation (i.e., hypostasis) and eventually, responsibility for the Other. As the human experience of having and being one's body cannot be governed by universal imperatives, the dignity of human corporeality already surpasses the robotics of human physiology. Reversely though, it is the Body that tames the consciousness from its tendency to alienate itself. Through the Body's direct access to matter, consciousness becomes directed to its real transcendental direction. Thus, a mutual respect between materiality and transcendence within the human subject is realized.

Levinas' graphic and elaborate discourse clearly shows that this is an authentic event between individuals of flesh and blood. Supposedly, this is conveniently proven on the condition that the corporeal nature of both the Self and the Other is established. While this task should be easy, a one-sided

34 Such serves as Levinas' basis to reject the disjunctive view of the body between being lived and physical. While we have seen the need to distinguish the Body from consciousness insofar as they are exclusively governed by their primordial mechanisms (inasmuch as the Body belongs to the world yet is also claimed by a Pure Ego that is in and for itself), Levinas nevertheless stresses the importance of the incorporation of the lived body and the physical body. The proponent assumes that such is possible because of the Body's substantiality and singularity - through the Body, we see a physique; and still with the Body, we find life. 
account of corporeality is seemingly provided. Earlier, one may notice that the Levinasian notion of corporeality is only made possible through the development of a project of transcendence by a subject who is purged by sensibility and taught to be for the Other.

Despite the presence of many bodily instances that cite the transition of the ontological subject towards a being-for-the-Other, we find in Totality and Infinity Levinas' reluctance to logically confront such ethical encounter by way of opposition. ${ }^{35}$ And so perhaps, it is better to develop a descriptive discourse of the Other through the Face than to entrust the reality of the Other on a rhetorical resolution - the negation of the subject. However, there still exists a need to overcome Levinas' reluctance to enflesh the Face as though it is a phenomenon. ${ }^{36}$ And so, a corporeal regard of the Other is possible if instead of being phenomenon, the Face by her Facing, will be considered as a vital metaphor. ${ }^{37}$

In overcoming Levinas' reluctance to find corporeality in the Other, it is realized that embodiment does not necessarily connote phenomenalization. With the steady guard of the exigency to escape, the Body cannot be regarded as a mere appearance, and corporeality cannot be a mere by-product of consciousness' effort to contain the world. Finally, such also indicates a release of corporeality's usual context within totality. With such liberating look on embodiment it becomes a very human path towards the Infinite, where one finds the Good.

${ }^{35} \mathrm{He}$ writes: "the presentation of being in the face does not leave any logical place for its contradictory." Levinas, Totality and Infinity, 201.

${ }^{36}$ Levinas, Ethics and Infinity (Conversations with Philippe Nemo), trans. by Richard A. Cohen, (Quezon City: Claretian Publications, 1997), 85.

37 The Face of the Other as a vital metaphor explains corporeality in a Face that is Facing. The Face directly reveals the Other through its primordial signs of nudity and uprightedness. As such features express an invitation to violence (which includes its openness to phenomenolization), the Face through its attachment to a lived-body finds a way to render a meaning that exceeds what its presence provides. In other words, life renders the Face the capacity to reveal more than what its finitude can show. This capacity now makes the Face speak: through Facing me, the Other reminds me of a commandment that directly appeals to human (hence embodied) existence: Thou shall not kill. Such is rendered through two important messages: Don't touch me. -- the prohibition, and Help! - the plea.

The Face by its Facing indirectly gives the subject the general condition of being which entices the subject to a relation that is directed to transcendence. An orientation to Spirit and Matter leads to the realization of how to exist in Economy (e.g., the need to be fed, compensated, etc.) and struggle for Transcendence (by living for the Other). Adriaan Peperzak, "Transcendence," in Ethics as First Philosophy: the Significance of the Philosophy of Emmanuel Levinas for Philosophy, Religion and Literature (New York: Routledge, 1995), 169. This also indirectly reveals the pre-eminence of a phase that is outside ontology, the ethical which exceeds its being a simple region of being (through human existence) and a branch of philosophy. ${ }^{37}$ Levinas mentions, "The encounter with the other offers us the first meaning, and in the extension of this encounter, we discover all the others." Emmnauel Levinas, "Reality has Weight," in Is It Righteous to Be? Interviews with Emmanuel Levinas, ed. by Jill Robbins (California: Stanford University Press, 2001), 160. 


\section{The Body and the Good}

Levinas' notion of corporeality shows a dialectic that struggles from the phenomenology of a sensible subject towards an ethics of transcendence. What allowed this possibility is the courageous confrontation that human beings are: 1) more than their thoughts, as 2) they are made of flesh and blood and that 3) they are in and thus influenced by the world. Perhaps by the conviction that existence can also be obscure to consciousness, Levinas is able to explain how an egoistic subject is humbled. Through the work of corporeality, the subject is weakened by pain despite virility, suffers despite being at home and longs for a sublime unknown in the face of plenitude. This study concludes with the following points:

a) Ethics begins with vital existence. Even if Ethics formally begins with the encounter of the Other, it is nevertheless indebted to an earlier relation which could be facile and organic yet is very significant to existence. This is most evident with the subject being equipped with a sensibility that is radically brewed to transcend. This also explains why the defense of life is the most fundamental Levinasian contention. When radicalized however, this defense can be defeated still by the Self who is willing to die for the Other. At this stance, death is not a defamation but a consecration.

b) Subjective sensibility sanctifies human sentiency-an attribute that makes the human being at par with the brutes. Through the ethical encounter, sensitivity (as reception where qualities are taken in) is profoundly elevated to sensibility (as being affected by the non-qualifiable where the subject is taken out). Such connotes two transitions: 1.) from the psychology of the offended to an ethics of dispensation, and 2.) from retribution to forgiveness and healing.

c) The Instruction of the Good by the Trace of the Face. The Face albeit her fundamental concreteness could not prescribe, its vital trace depicts ethics without any categorical and foreboding axiology. The Good in her transcendence and height could but visit the subject, through her epiphany in the Face and in the ethical encounter-her call despite being stern does not appropriate. Perhaps, such is the case because the Good (through the Other) is teaching the subject the way of the Transcendent, of the Infinite.

The Good in the finite is what Levinas calls goodness. Levinas considers goodness as the translation of the transcendent Good into the subject. In Otherwise than Being or Beyond Essence, we find him saying that goodness is an ontologically metamorphosed Good into essence that cannot be contained. While it strongly insinuates the reduction of the Good, it is nonetheless a 
reduction of an uncontainable essence. ${ }^{38}$ If we are to apply subjective sensibility, goodness then is a by-product of being affected by the Good as it claims its pre-original hold of the subject. By goodness, the existent is invested to obey the hidden Good-to be ethical; where the investiture is but a reminder of one's being chosen even without having chosen. ${ }^{39}$ Bluntly, goodness then is to be enslaved by the Good..$^{40}$

Such radical statement can be tempered by Levinas' previous claims. In Totality and Infinity, we find him saying that the Good governs the subject by goodness within the boundaries of human existence. In other words, its translation through an ethical act could only go as far as what human effort can exert. This does not mean however that the Good can already be regulated, particularly by the rules inscribed by nature and/or institutions (through laws). ${ }^{41}$ Indeed, transcendence belongs to the subject: "transcendence is the transcendence of the I." 42 But despite that, Levinas maintains the exteriority of the Good by saying that it is what disturbs the subject and his ethical gameplan. Being good then entails a subjectivity that gives up his will to welcome the surplus of value-the Transcendent Good, the Infinite, which now superintends his action. In Humanism and An-archy, Levinas writes: "to be dominated by the Good is precisely to exclude for oneself the very possibility of choice, of coexistence in the present." 43

While goodness is in the realm of being, the Good is always beyond being. This means to say that the Good does not stand as a fixed authority, it may escape its very command. This is then a very flexible designation that even if pre-originary, the subject's ordination to the Good can only be realized in an ethical event that involves the Other. Indeed, "goodness concerns a being which is revealed in the face..." 44

Department of Philosophy, University of Santo Tomas, Philippines

\section{References}

Bauman, Zygmunt, Life in Fragments: Essays in Postmodern Morality (Cambridge, Massachusetts: Blackwell Publishers, 1995).

Bernasconi, Robert and Simon Critchley, Re-reading Levinas (Bloomington: Indiana University Press, 1991).

38 Levinas writes: "Goodness will indeed show itself in ontology metamorphosed into essence, and to be reduced; but essence cannot contain it." Levinas, Otherwise than Being or Beyond Essence, 137.

39 Ibid., 118.

40 Ibid.

${ }^{41}$ Levinas, Totality and Infinity, 305.

42 Ibid.

${ }^{43}$ Levinas, "Humanism and An-archy," in Humanism of the Other, trans. by NidraPoller (Urbana: Illinois University Press, 2003), 53.

${ }^{44}$ Loc. cit. 
Bernasconi, Robert, "A Love that is Stronger than Death: Sacrifice in the thought of Levinas, Heidegger and Bloch," in ANGELAKI Journal of the Theoretical Humanities, 7:2 (August 2002), 1-8.

Bloechl, Jeffrey ed., The Face of the Other and the Trace of God (New York: Fordham University Press, 2000).

Bernasconi, Robert, "No Exit: Levinas' Aporetic Account of Transcendence," in Research in Phenomenology, 35 (2005), 101-117.

Diprose, Rosalyn, Corporeal Generosity: on Giving with Nietzsche, Merleau-Ponty and Levinas (Albany: State University of New York Press, 2002).

Husserl, Edmund, Ideas: General Introduction to Pure Phenomenology, trans. by WR Boyce Gibson (London: George Allen and Unwin Ltd., 1952). The Essential Husserl: Basic Writings in Transcendental Phenomenology, ed. Donn Welton (USA: Indiana University Press, 1999).

Levinas, Emmanuel. Alterity and Transcendence. trans. by Michael B. Smith (New York: Columbia University Press, 1999). Difficult Freedom: Essays on Judaism (Baltimore: The John Hopkins University Press, 1998). , Discovering Existence with Husserl (Evanston, Illinois: Northwestern University Press, 1990). , Entre Nous: Thinking-of-the-Other, trans. by Michael B. Smith and Barbara Harshav (New York: Columbia University Press, 1998). Ethics and Infinity (Conversations with Pbilippe Nemo), trans. by Richard A. Cohen (Quezon City: Claretian Publications, 1997). , Existence and Existents (The Hague: Nijhoff, 1978). Humanism of the Other, trans. by NidraPoller (Urbana: University of Illinois Press, 2003). , Is it Righteous to Be? Interviens with Emmanuel Levinas, ed. by Jill Robbins (California: Standford University Press, 2001). On Escape (De l'évasion), trans. by Bettina Bergo (Stanford, California: Stanford University Press, 2003). Otherwise than Being or Beyond Essence, trans. by Alphonso Lingis (Dordrecht, Netherlands: Kluwer Academic Press, 1981). 1993). Outside the Subject (Stanford, CA: Stanford University Press, The Theory of Intuition in Husserl's Phenomenology (Evanston: Northwestern University Press, 1995). , Time and the Other and Additional Essays, trans. by Richard A. Cohen (Pittsburgh, PA: Duquesne University Press, 1987).

, Totality and Infinity: an Essay on Exteriority, trans. by Alphonso Lingis (Pittsburgh, PA: Duquesne University Press, 2001).

Llewelyn, John. Emmanuel Levinas: the Genealogy of Ethics (London: Routledge, 1995).

Peperzak, Adriaan Theodoor ed., Ethics as the First Philosophy: the Significance of Emmanuel Levinas for Pbilosophy, Religion and Literature (New York: Routledge, 1995). 
ed., To the Other: an Introduction to the Philosophy of Emmanuel Levinas (West Lafayette, Ind.: Purdue University Press, 1993). 